\title{
Separation via Flotation, Spectrophotometric Speciation, and Determination of Vanadium(IV) in Wastes of Power Stations
}

\author{
Magda Ali AKL, ${ }^{\dagger}$ Ahmed A. El-Asmy, and Wafaa M. YosseF \\ Chemistry Department, Faculty of Science, Mansoura University 35516, P. O. Box 70, Mansoura, Egypt
}

\begin{abstract}
1-(2-Hydroxy-4-methoxybenzophenone)-4-phenylthiosemicarbazone (HMBPT) was investigated as a new reagent for the flotation of vanadium(IV). At $\mathrm{pH} \sim 1.5$, vanadium(IV) forms a 1:1 pale-violet complex with HMBPT in aqueous solution. An intense clear violet layer was formed after flotation, by adding an oleic acid (HOL) surfactant. The composition of the float was 1:1 [V(IV)]:[HMBPT]. A highly selective and sensitive spectrophotometric procedure was proposed for the determination of microamounts of V(IV) as its floated complex. The molar absorptivities of the V(IV)-HMBPT and V(IV)-HMBPT-HOL systems were $0.4 \times 10^{4}$ and $0.12 \times 10^{5} \mathrm{~L} \mathrm{~mol}^{-1} \mathrm{~cm}^{-1}$ at $560 \mathrm{~nm}$, respectively. The formation constants of the species formed in the presence and absence of $\mathrm{HOL}$ were $4.6 \times 10^{7}$ and $8.7 \times 10^{5} \mathrm{~L} \mathrm{~mol}^{-1}$, respectively. Beer's law was obeyed up to $1 \times 10^{-4} \mathrm{~mol} \mathrm{~L}^{-1}$ in the aqueous layer as well as in the oleic acid layer. The HMBPT-V(IV) complexes formed in the aqueous solution and scum layer were characterized by elemental analysis, infrared and UV spectrophotometric studies. The mode of chelation between V(IV) and HMBPT is proposed to be due to a reaction between the protonated bidentate HMBPT ligand and $\mathrm{V}(\mathrm{IV})$ through the $\mathrm{S}=\mathrm{C}$ and $\mathrm{N}=\mathrm{C}$ groups. Interferences from various foreign ions were avoided by adding excess HMBPT and/or $\mathrm{Na}_{2} \mathrm{~S}_{2} \mathrm{O}_{3}$ as a masking agent. The proposed flotation ${ }^{1}$ method was successfully applied to the analysis of V(IV) in synthetic mixtures, wastes of power stations, simulated samples and in real ores. The separation mechanism is discussed.
\end{abstract}

(Received February 14, 2005; Accepted April 4, 2005)

Because the chemical and physical properties of a metal species depend very much on oxidation state, an accurate determination of each species is important to evaluate the potential risk of some metals. The importance of the simultaneous determination of vanadium in different oxidation sates can be attributed to a number of reasons: (i) Environmental. Vanadium is emitted into the environment from vanadium refineries, iron and steel industries, and chemical industries. Among the latter are the phosphate industries, which can be a major source of vanadium pollution. ${ }^{1}$ Due to an increase in production by these industries, there has been concern about increases in the environmental levels of vanadium, a phenomenon that needs to be monitored closely. (ii) Biological. Vanadium is an essential trace element with specific physiological functions. However, numerous reports have warned of carcinogenic and other toxic effects of vanadium, resulting from excessive industrial exposure. ${ }^{1} \quad$ Studies have shown that vanadium, when administered as vanadate, is physiologically more active in fish than other species of vanadium. ${ }^{2}$ (iii) Industrial. Vanadium metal is present in alloys and other industrially important materials. It can be used as a catalyst in numerous industrial processes, e.g. the Stretford, Unissulf, Shafer and Sulfolin processes. $^{3}$ In these processes (and in alloys) vanadium is capable of existing simultaneously in its different valence states. For a thorough understanding of the chemistry involved in these processes, the determination of vanadium in its different oxidation states is essential. (iv) Power Stations. Vanadium can be found in trace amounts in fossil fuels in power stations. The corrosion related to compounds of vanadium is usually

$\dagger$ To whom correspondence should be addressed.

E-mail: magdaakl_59@hotmail.com associated with super heaters and reheaters in boilers fired with heavy oil. The ash of which is the source of vanadium. Ash fouling and corrosion are major problems when burning heavy oils, the ash deposits jeopardize heat transfer to metallic surfaces and cause corrosion for the combustion hardware, thus decreasing its lifetime. In gas turbines, ash reduces the aerodynamic path for gas flue, and therefore the turbine performance. The values given in the literature ${ }^{4}$ show that more than $0.32 \mathrm{~cm}$ thick deposit can cause a $10 \%$ decrease in the turbine power. Vanadium is oxidized to different vanadates. Molten vanadates, present as deposits on metal, can flux oxide scales. Furthermore, the presence of vanadium accelerates the diffusion of oxygen through the fused salt layer to the metal substrate. Vanadium appears in fuel in the form of oil-soluble porphyrins. These organic vanadium compounds decompose in the gas stream to give mainly $\mathrm{V}_{2} \mathrm{O}_{5}$. Vanadium pentoxide is most damaging, since due to its low melting point $\left(690^{\circ} \mathrm{C}\right)$ it is present as a liquid at normal combustion temperatures. The formation mechanism of vanadium compounds can be explained as follows. ${ }^{5}$ At high temperature $\left(\sim 1370^{\circ} \mathrm{C}\right.$, low oxygen zones), non-volatile vanadium tetroxide $\left(\mathrm{V}_{2} \mathrm{O}_{4}\right)$ is formed. Vanadium pentoxide is formed from the tetroxide at low temperature $\left(\sim 800^{\circ} \mathrm{C}\right.$, high oxygen zones). In fact, deposits are observed to comprise both oxides, although the tetroxide oxidizes to the pentoxide in excess air. Vanadium salts of a low-melting point deposit on heat transfer surfaces as tenacious clinker and ash, and decreases the heat transfer. The ingredients of the residues mostly combine with vanadium pentoxide to form non-corrosive vanadates that have a high melting point and are friable and less adherent. Thus, it is necessary to inhibit these deposits manually, or by using inhibitors that are often metalo-organic compounds such as magnesium organo-metallic 
compounds. Because vanadium is a major pollutant of the environment and its compounds are toxic, even such materials as crude ore dust cause toxic effects, especially in waste water coming out from boilers after the specified washing of furnaces and heat transfer areas. Hence, its determination is one of great interest.

The significance of vanadium speciation is that two oxidation states, V(IV) and V(V), have different nutritional and toxic properties. Therefore, it is important, from an analytical point of view, to develop sensitive, selective, rapid and cost-effective methods for quantitative speciation, even when the element is present in trace amounts. Although many studies have been devoted to metal speciation, little work on the speciation of vanadate $\left(\mathrm{VO}_{3}{ }^{-}\right)$and vanadyl ions $\left(\mathrm{VO}^{2+}\right)$ has been reported.

In order to achieve accurate and reliable analytical results, preconcentration and matrix-analyte separation are needed when the analyte concentration is too low to be determined directly by spectrophotometry, or when the matrix elements interfere with the determination. Many separation and preconcentration techniques $^{6-8}$ for the determination of $\mathrm{V}(\mathrm{V})$ and $\mathrm{V}(\mathrm{IV})$ species have been proposed, including chelation and extraction, precipitation and the use of ion-exchange resins. However, many of these methodologies are performed in batch, thus requiring large sample volumes in order to reach low detection limits. Further, these systems have higher contamination risks and are not practical for applications to routine analysis. On the other hand, methods for the separation and preconcentration of metals by flotation, followed by their spectrophotometric determination, have increased in popularity in recent years. ${ }^{9-18}$ A literature survey showed that ion-flotation followed by spectrophotometric determination of V(IV) is rarely reported. ${ }^{19}$ Also, no attempt has been found for using 1-(2-hydroxy-4methoxybenzophenone)-4-phenylthiosemicarbazone (HMBPT) in this concern. Fortunately, in this investigation, HMBPT found its role for a direct spectrophotometric determination of $\mathrm{V}(\mathrm{IV})$, and also gave a high performance in the preconcentration of V(IV) via its flotation as a HMBPT-V(IV) colligend.

In present work, a procedure was proposed for preconcentrative flotation-separation and speciation of vanadium(IV) using HMBPT as a complexing agent and HOL as a surfactant. A number of experimental variables were evaluated, e.g. the $\mathrm{pH}$, concentration of metal and ligand and temperature. In addition to measurements of V(IV) in synthetic and simulated samples, other samples, such as river water and seawater samples and wastes from power stations, were also analyzed to show the versatility and specificity of the reagent HMBPT. The feasibility of the flotation and specificity of the reagent HMBPT enabled easing the preconcentration of traces of V(IV) with an enhancement of the measurements. Since $\mathrm{V}(\mathrm{IV})$ was determined directly in the scum layer by spectrophotometry, the problems of elution disappeared, and most of the interferences were suppressed.

\section{Experimental}

\section{Chemicals and solutions}

Unless otherwise stated, all chemical reagents used in the study were of analytical grade with high purity. Doubly distilled water (DDW) was used throughout this work.

A HMBPT stock solution, $1 \times 10^{-2} \mathrm{~mol} \mathrm{~L}^{-1}$, was freshly prepared by dissolving $0.377 \mathrm{~g}$ of HMBPT in $70 \mathrm{~mL}$ ethanol and $30 \mathrm{~mL}$ of DDW.

An oleic acid (HOL) stock solution, $6.36 \times 10^{-2} \mathrm{~mol} \mathrm{~L}^{-1}$, was

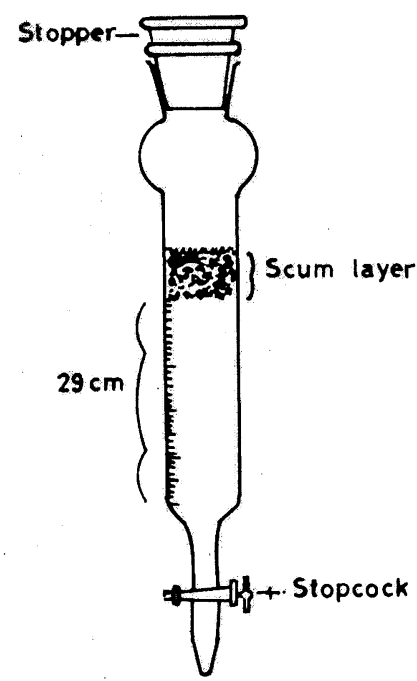

Scheme 1 Flotation cell (type 1).

prepared by dispersing $20 \mathrm{~mL}$ of oleic acid in one liter of kerosene.

A vanadium(IV) stock solution of $\mathrm{VOCl}_{2}, 1 \times 10^{-2} \mathrm{~mol} \mathrm{~L}^{-1}$, was taken from the standard solution.

A vanadium $(\mathrm{V})$ stock solution $\left(1 \times 10^{-2} \mathrm{~mol} \mathrm{~L}^{-1}\right)$ was prepared by dissolving $0.117 \mathrm{~g}$ of $\mathrm{NH}_{4} \mathrm{VO}_{3}$ in $100 \mathrm{~mL}$ of DDW.

A stock solution of $1 \times 10^{-2} \mathrm{~mol} \mathrm{~L}^{-1}$ ethylenediaminetetraacetic acid, disodium salt, was prepared by dissolving $3.74 \mathrm{~g}$ of EDTA in one liter of DDW, and standardized by a standard solution of $\mathrm{MgSO}_{4} \cdot 7 \mathrm{H}_{2} \mathrm{O}$.

A $1 \%(w / v)$ solution of ascorbic acid (Analar grade) was freshly prepared each day, immediately prior to analysis.

\section{Instrumentation}

All glassware were soaked overnight in chromic mixture $\left(\mathrm{K}_{2} \mathrm{Cr}_{2} \mathrm{O}_{7}+\right.$ concentrated $\left.\mathrm{H}_{2} \mathrm{SO}_{4}\right)$, rinsed thoroughly with DDW and dried in a vacuum oven.

\section{Flotation cell}

Two types of flotation cells were used throughout this study. ${ }^{20}$ The first type (type 1), Scheme $1,{ }^{21}$ was a tube of $1.2 \mathrm{~cm}$ inner diameter and $29 \mathrm{~cm}$ length with a stopcock at the bottom. Such a cell was used to study the factors affecting the flotation efficiency. The second type (type 2) was a cylindrical tube of 6 $\mathrm{cm}$ inner diameter and $45 \mathrm{~cm}$ length with a stopcock at the bottom and a quick-fit stopper at the top. This cell was used to separate the investigated analyte from a relatively large volume.

\section{Spectrophotometric measurements}

The spectrophotometric data were recorded on a Unicam $U_{2-100}$ $\mathrm{UV} / \mathrm{V}$ is spectrophotometer.

\section{Infrared studies}

The infrared spectra of HMBPT and its solid complexes were recorded on a Mattson 5000 FTIR spectrophotometer using $\mathrm{KBr}$ discs.

\section{pH-measurements}

The $\mathrm{pH}$ values of all solutions prepared before flotation were carried out using HANNA Instruments 8519 digital pH-meter.

\section{Elemental analysis}

The carbon and hydrogen contents of the formed HMBPT- 
<smiles>COc1ccc(/C(=N\NC(=S)Nc2ccccc2)c2ccccc2)c(O)c1</smiles>

Scheme 2 1-(2-Hydroxy-4-methoxybenzophenone)-4-phenylthiosemicarbazone (HMBPT)

V(IV) complexes were determined at the Micro-analytical Unit, Cairo University, Egypt. The analyses of V were carried out by well-known standard methods. ${ }^{22}$ Chloride was gravimetrically determined as $\mathrm{AgCl}$.

\section{Preparations}

Preparation of 1-(2-hydroxy-4-methoxybenzophenone)-4-phenylthiosemicarbazone $\left(\mathrm{C}_{21} \mathrm{H}_{19} \mathrm{~N}_{3} \mathrm{O}_{2} \mathrm{~S}\right.$, HMBPT). HMBPT (Scheme 2) was prepared by the condensation of 2-hydroxy-4methoxybenzophenone and 4-phenylthiosemicarbazide in absolute ethanol. The reaction mixture was heated under reflux for $3 \mathrm{~h}$. Upon cooling the solution, a white precipitate was formed which was removed by filtration and washed with ethanol and diethyl ether, and finally dried. The compound was characterized by IR, ${ }^{1} \mathrm{HNMR}$ and mass spectra (data not shown).

Preparation of solid complexes. In the aqueous solution: The solid complex was prepared by mixing equimolar amounts of HMBPT and V(IV) ions in an aqueous ethanol solution. The colored solid complexes that precipitated were filtered off and recrystallized from ethanol, and then dried under a vacuum.

The scum layer: The HMBPT-V(IV) complex in the scum layer was obtained by mixing equimolar amounts of HMBPT and $\mathrm{V}(\mathrm{IV})$ ions $\left(1 \times 10^{-2} \mathrm{~mol} \mathrm{~L}^{-1}\right)$ in the presence of $3 \mathrm{~mL}(6.36$ $\times 10^{-2} \mathrm{~mol} \mathrm{~L}^{-1}$ ) of oleic acid. The float (solid complex) was gathered by filtration in a sintered glass gooch $\left(\mathrm{G}_{4}\right)$, washed several times with DDW and ethanol, and finally with diethyl ether. The precipitate was dried in an oven at $80^{\circ} \mathrm{C}$ and preserved in a desiccator.

\section{Analytical procedures}

General procedure. A $3 \mathrm{~mL}$ aliquot containing $2 \times 10^{-5} \mathrm{~mol} \mathrm{~L}^{-1}$ of V(IV) was mixed with HMBPT $\left(1 \times 10^{-4} \mathrm{~mol} \mathrm{~L}^{-1}\right)$ and $2 \mathrm{~mL}$ of $0.1 \mathrm{~mol} \mathrm{~L}^{-1} \mathrm{Na}_{2} \mathrm{~S}_{2} \mathrm{O}_{3}$, then, $3 \mathrm{~mL}$ DDW were added. The $\mathrm{pH}$ was adjusted at $\approx 1.5$ by adding drops of $0.1 \mathrm{M} \mathrm{HNO}_{3}$. The solution was then transferred quantitatively to a flotation cell (type 1) and completed to $10 \mathrm{~mL}$ with DDW water. The cell was shaken well for a few seconds to ensure complete complexation. To this solution, $3 \mathrm{~mL}$ of $\mathrm{HOL}\left(3 \times 10^{-3} \mathrm{~mol} \mathrm{~L}^{-1}\right)$ was added, and the cell was then inverted upside down many times by hand. After complete separation, a colored solution containing the V(IV)-HMBPT complex was separated and directly measured spectrophotometrically or colorimetrically at $560 \mathrm{~nm}$ against a blank containing the same concentrations of the constituents as in the sample solution without the analyte.

The separation efficiency $(F, \%)$ was calculated by applying the following relation:

$$
F_{\mathrm{V}(\mathrm{IV})}=\left[C_{\mathrm{s}} / C_{\mathrm{i}}\right] \times 100 \% \text {. }
$$

Here $C_{\mathrm{i}}$ and $C_{\mathrm{s}}$ denote the initial and the scum concentrations of $\mathrm{V}(\mathrm{IV})$, respectively.

Determination of $V(I V)$ and $V(V)$ in each other's presence. Into a $50 \mathrm{~mL}$ measuring flask, $10 \mathrm{~mL}$ of a solution containing a definite amount of both V(IV) and V(V) (each $2 \times 10^{-5} \mathrm{~mol} \mathrm{~L}^{-1}$ ) and $3 \mathrm{~mL}$ of $1 \%(\mathrm{w} / \mathrm{v})$ ascorbic acid (freshly prepared) were mixed. The $\mathrm{pH}$ was adjusted to 1.5 using drops of $0.1 \mathrm{M} \mathrm{HNO}_{3}$. This mixture was shaken well for 5 min to ensure complete reduction of $\mathrm{V}(\mathrm{V})$ into $\mathrm{V}(\mathrm{IV})$. Then, $2 \mathrm{~mL}$ of HMBPT $\left(1 \times 10^{-4}\right.$ mol L ${ }^{-1}$ ) was added, and the mixture was again shaken well for 2 min to ensure complete complexation of V(IV) with HMBPT. The contents were then quantitatively transferred to the flotation cell; the same steps of flotation and spectrophotometric determination of the floated HMBPT-V(IV) species were followed as described before. The total concentration of vanadium, as V(IV), was calculated from a calibration curve that was constructed by following the same flotation procedure, in which the concentration of the standard V(IV) in the colored scum covered the range $(1-10) \times 10^{-5} \mathrm{~mol} \mathrm{~L}^{-1}$, and measured spectrophotometrically or colorimetrically at $560 \mathrm{~nm}$ against a blank containing the same concentrations of the constituents as in the sample solution without the analyte. The concentration of vanadium $(\mathrm{V})$ was calculated as the difference between the total vanadium concentration and the $\mathrm{V}(\mathrm{IV})$ concentration.

Back titration of $V(I V)$. Into a conical flask, $5 \mathrm{~mL}$ of a $\mathrm{V}(\mathrm{IV})$ solution, $2 \mathrm{~mL} \mathrm{~L}$-ascorbic acid and $5 \mathrm{~mL}$ of EDTA $(0.01 \mathrm{~mol}$ $\mathrm{L}^{-1}$ ) were transferred. Excess EDTA was titrated against a standardized solution of $\mathrm{Pb}\left(\mathrm{NO}_{3}\right)$ using Xylenol orange (solid) at $\mathrm{pH} 2.0-2.5$ using $\mathrm{HNO}_{3}$ and $\mathrm{NH}_{4} \mathrm{OH}$. The end point was taken when the color changed from yellow to red.

\section{Sample analysis}

Real ore samples. Two certified reference materials were analyzed, namely lead-zinc sulfide ore-OCrO (COD 161-96) supplied by MBH Analytical Ltd. (Barnet, UK) and stream sediment SARM 52 prepared by MINTEX (Ranburg, Republic of South Africa).

A $0.5 \mathrm{~g}$ portion of each certified sample was completely dissolved in a Teflon beaker with a mixture of acid $(45 \mathrm{~mL}$ of $\mathrm{HF}, 15 \mathrm{~mL}$ of $\mathrm{H}_{2} \mathrm{SO}_{4}$ and $5 \mathrm{~mL}$ of $\mathrm{HNO}_{3}$ ). After complete dissolution, the solution was evaporated until dryness. The residue was dissolved in $20 \mathrm{~mL}$ of $\mathrm{HCl}(1: 1)$ and completed to $100 \mathrm{~mL}$ in a measuring flask using DDW. The previous steps of reduction, flotation and spectrophotometric determination were followed.

Natural water samples (recovery test). DDW, tank water, domestic water (from Mansoura city), seawater (from RasElbar, El-Areash, Gamasa and Marsi-Matroah cities) and waste water of Talkha and Demiata Power Stations were investigated by the proposed flotation methodology. Samples were filtered using a $0.45 \mu \mathrm{m}$ pore size membrane filter to remove any suspended particulate matter, and immediately treated with few milliliters of conc. $\mathrm{HNO}_{3}$ to prevent the possible hydrolytic precipitation of some mineral salts.

Different concentrations of V(IV), i.e. 0.5 and $1 \times 10^{-5} \mathrm{~mol}$ $\mathrm{L}^{-1}$ were introduced into $20 \mathrm{~mL}$ aliquots of water samples; $2 \mathrm{~mL}$ of $1 \times 10^{-2} \mathrm{~mol} \mathrm{~L}^{-1}$ HMBPT were added; the same previous steps of flotation and spectrophotometry were carried out and the recovery percentages were calculated.

\section{Results and Discussion}

Flotation-separation of $V(I V)$

In the solvent sublation technique, oleic acid imposed itself as 


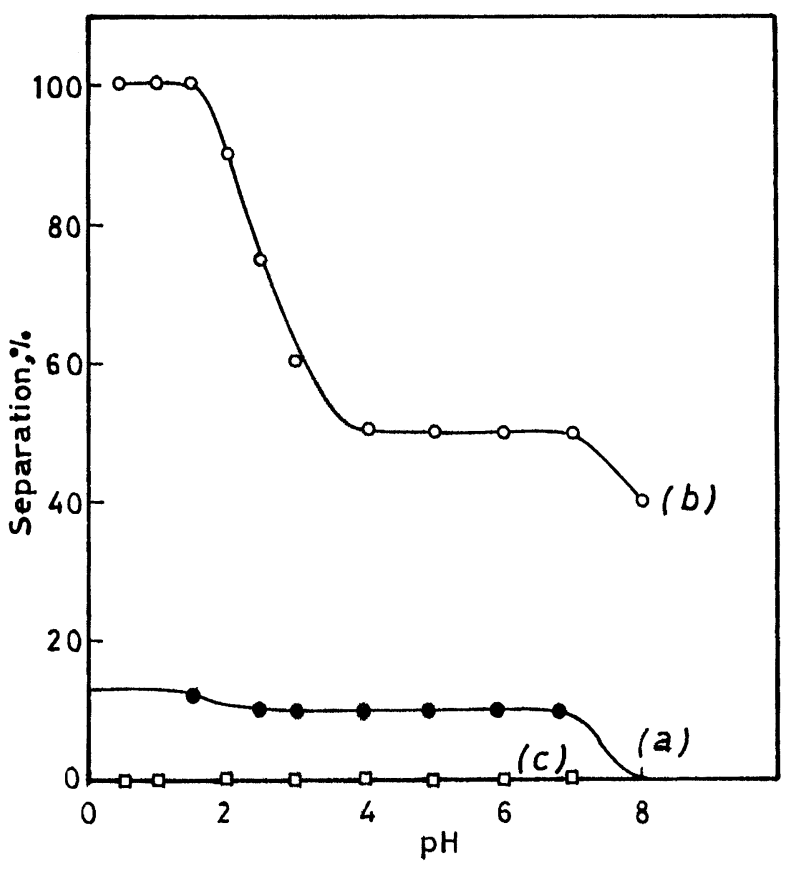

Fig. 1 Influence of the hydrogen-ion concentration on the separation efficiency of: curve a, $2 \times 10^{-5} \mathrm{~mol} \mathrm{~L}^{-1} \mathrm{~V}(\mathrm{IV})$ in the absence of HMBPT; curve b, V(IV) in the presence of $1 \times 10^{-4} \mathrm{~mol}$ $\mathrm{L}^{-1} \mathrm{HMBPT}$ and curve c, $\mathrm{V}(\mathrm{V})$ in the absence or in the presence of 1 $\times 10^{-4} \mathrm{~mol} \mathrm{~L}^{-1} \mathrm{HMBPT}$ each using $3 \times 10^{-3} \mathrm{~mol} \mathrm{~L}^{-1} \mathrm{HOL}$.

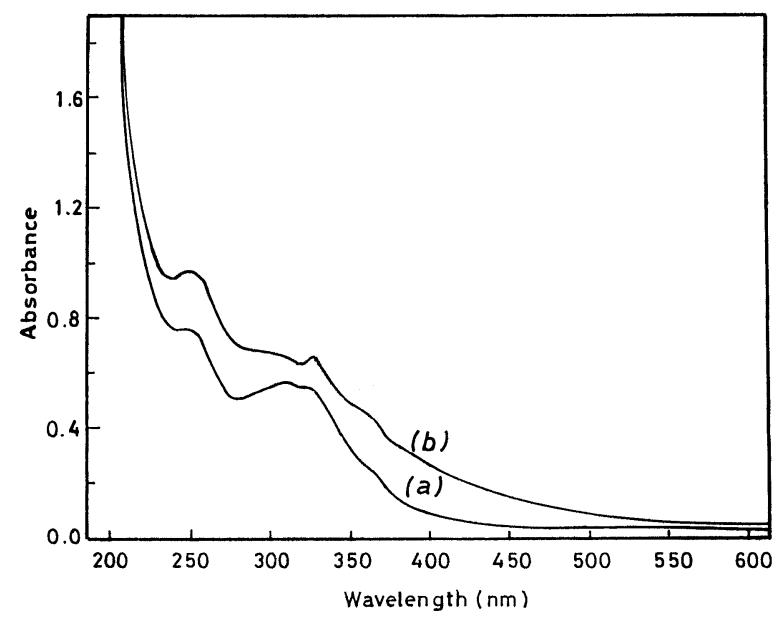

Fig. 2 Absorption spectra: curve a, floated HMBPT $\left(2.5 \times 10^{-5} \mathrm{~mol}\right.$ $\left.\mathrm{L}^{-1}\right)$ alone or floated with $\mathrm{V}(\mathrm{V}) 2 \times 10^{-5} \mathrm{~mol} \mathrm{~L}^{-1}$ and curve $\mathrm{b}$, floated HMBPT $\left(5 \times 10^{-5} \mathrm{~mol} \mathrm{~L}^{-1}\right)$ or floated with $2 \times 10^{-5} \mathrm{~mol} \mathrm{~L}^{-1} \mathrm{~V}(\mathrm{~V})$.

an excellent surfactant for the selective separation of some metal ions as soluble intense colored compounds in the scum layer. ${ }^{9-18}$ Consequently, such a process enabled and facilitated the spectrophotometric determination of the analyte.

\section{Influence of the hydrogen-ion concentration}

Vanadium(IV) and vanadium(V) have many complex forms in water that change in accordance with the solution $\mathrm{pH}$ and their concentration..$^{23}$ It is known that in the $\mathrm{pH}$ range $2-6$, the main species of vanadium $(\mathrm{V})$ is the decavanadate ion, $\mathrm{V}_{10} \mathrm{O}_{28}{ }^{6-}$, which can exist in several protonated forms, and which changes to the

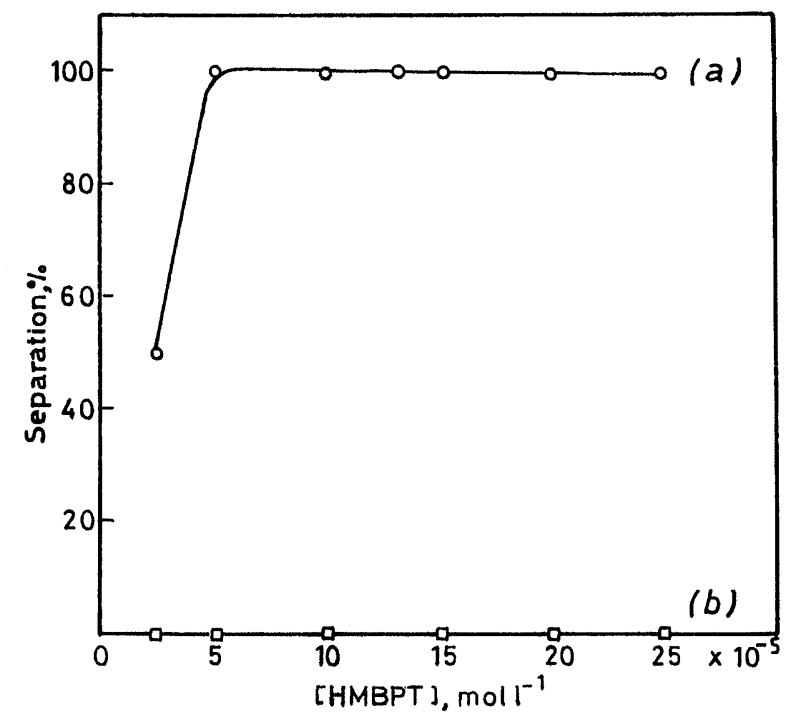

Fig. 3 Influence of [HMBPT] on the separation efficiency of $5 \times$ $10^{-5} \mathrm{~mol} \mathrm{~L}^{-1} \mathrm{~V}(\mathrm{IV})$ (curve a) and $5 \times 10^{-5} \mathrm{~mol} \mathrm{~L}^{-1} \mathrm{~V}(\mathrm{~V})$ (curve b) using $3 \times 10^{-3} \mathrm{~mol} \mathrm{~L}^{-1} \mathrm{HOL}$ at $\mathrm{pH} \approx 1.5$.

dioxovanadium(V) ion, $\mathrm{VO}_{2}{ }^{+}$, below $\mathrm{pH} 2$. In contrast, vanadium(IV) exists as the oxovanadium(IV) ion, $\mathrm{VO}^{2+}$, in acidic solution; this cation readily changes to the anion, $\mathrm{V}_{18} \mathrm{O}_{42}{ }^{12-}$, at about $\mathrm{pH} \sim 4 .^{2}$

A conductive series of experiments was carried out to float $\mathrm{V}(\mathrm{IV})$ using HOL alone. A suitable concentration of the analyte $\left(2 \times 10^{-5} \mathrm{~mol} \mathrm{l}^{-1}\right)$ was taken in the floatation cell and a sufficient quantity of HOL surfactant $\left(1 \times 10^{-3} \mathrm{~mol} \mathrm{~L}^{-1}\right)$, which is still less than the critical micelle concentration $(\mathrm{CMC})$, was added to float V(IV) at different $\mathrm{pH}$ values. The data in Fig. 1 (curve a) prove that not more than $12.5 \%$ of the analyte was separated at any $\mathrm{pH}$. Such a separation percent is not satisfactory from an analytical point of view in which V(IV) floats as V(IV)-oleate. Accordingly, many trials were carried out to separate V(IV) quantitatively and selectively using different organic collectors. Of these, HMBPT imposed itself as an excellent collector. The data in Fig. 1 (curve b) show that the complete separation $(\approx 100 \%)$ of $\mathrm{V}(\mathrm{IV})$ was obtained in the $1-2 \mathrm{pH}$ range in the presence of $2 \times 10^{-4} \mathrm{~mol} \mathrm{~L}^{-1}$ of HMBPT. In such a case, $\mathrm{V}(\mathrm{IV})$ floated in the form of the V(IV)-HMBPT complex as an intense purple color.

At higher $\mathrm{pH}$ values, the separation flotation percentage was generally diminished, partly due to the formation of the anionic $\mathrm{V}_{18} \mathrm{O}_{42}{ }^{12-}$ species (at $\left.\mathrm{pH} \mathrm{4}\right)^{2}$ and partly due to the formation of sodium oleate, in an alkaline medium, consuming the amount of HOL required for collecting all of the analyte complex species.

\section{Behavior of vanadium $(V)$}

The flotation of $\mathrm{V}(\mathrm{V})$ with HMBPT, on the other hand, was extremely poor and no quantitative flotation of $\mathrm{V}(\mathrm{V})$ was attained in the $\mathrm{pH}$ range $1-10$. $\mathrm{V}(\mathrm{IV})$ was floated at $\mathrm{pH} \sim 1.5$ at which $\mathrm{V}(\mathrm{V})$ was not floated at all, as shown in Fig. 1(curve c). In order to prevent reduction of $\mathrm{V}(\mathrm{V})$ to $\mathrm{V}(\mathrm{IV}), 2 \mathrm{~mL}$ of hot conc. $\mathrm{HNO}_{3}$ was added into the aqueous solution before addition of the HMBPT ligand. To confirm this behavior, a trial was made to float HMBPT at two different concentrations viz. $2.5 \times$ $10^{-5} \mathrm{~mol} \mathrm{~L}^{-1}$ and $5 \times 10^{-5} \mathrm{~mol} \mathrm{~L}^{-1}$ in the presence and absence of $2 \times 10^{-5} \mathrm{~mol} \mathrm{l}^{-1}$ of $\mathrm{V}(\mathrm{V})$. The results of this trial showed that a pale yellow color is noticed in the scum layer in both the 


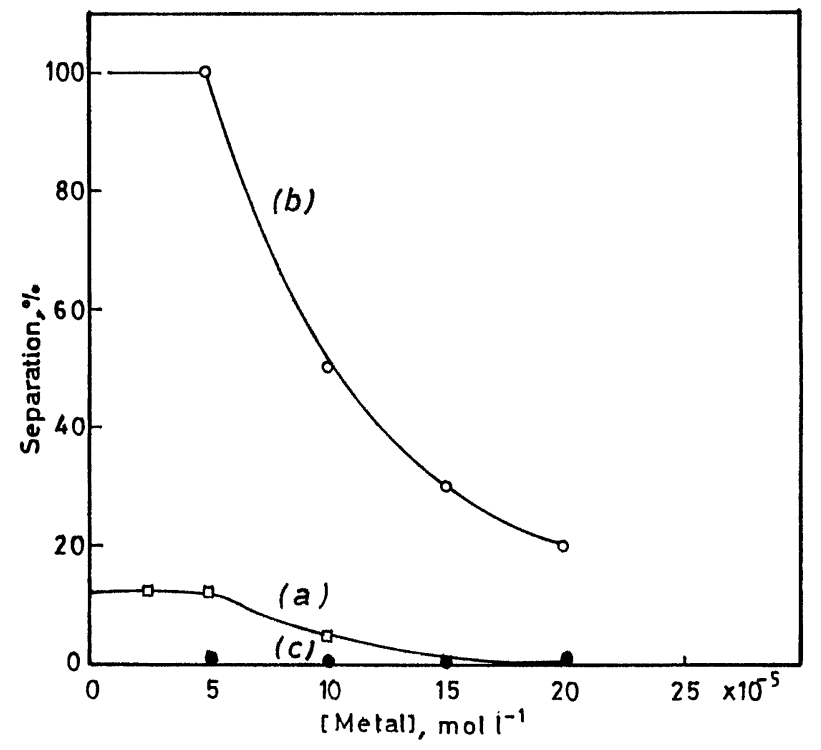

Fig. 4 Separation efficiency of different concentrations of V(IV) and $\mathrm{V}(\mathrm{V})$, at $\mathrm{pH} \approx 1.5$ using $3 \times 10^{-3} \mathrm{~mol} \mathrm{~L}^{-1} \mathrm{HOL}$ (curve a), $\mathrm{V}(\mathrm{IV})$ without HMBPT (curve b), V(IV) with $5 \times 10^{-5} \mathrm{~mol} \mathrm{~L}^{-1} \mathrm{HMBPT}$ and $\mathrm{V}(\mathrm{V})$ with or without $5 \times 10^{-5} \mathrm{~mol} \mathrm{~L}^{-1} \mathrm{HMBPT}$ (curve c).

absence and presence of $\mathrm{V}(\mathrm{V})$. The absorption spectra of HMBPT-V(V) system are graphically represented in Fig. 2, in which some important observations can be noticed. Firstly, the maximum absorption bands are the same in the two cases, ligand alone or ligand plus $\mathrm{V}(\mathrm{V})$. This finding completely excludes the complexation between $\mathrm{V}(\mathrm{V})$ and HMBPT. Secondly, the difference in the absorbance values (Fig. 2, curves $a$ and b) can be attributed to only the difference in the ligand concentration regardless of the concentration of $\mathrm{V}(\mathrm{V})$. These observations clearly indicate that the flotation may be related to only HMBPT.

\section{Influence of the HMBPT and V(IV) concentrations}

At $\mathrm{pH} \approx 1.5$, a conductive series of experiments was carried out to investigate the type of interaction between $\mathrm{V}(\mathrm{IV})$ and HMBPT in solution. It was found that V(IV) forms a $1: 1$ complex with HMBPT, and complete floatation-separation was achieved for any amount of HMBPT added (Fig. 3). This simplified the procedure for the analytical separation and determination of $\mathrm{V}(\mathrm{IV})$, especially in samples containing unknown amounts of the analyte.

To confirm the previous data, another series of experimental work was carried out by changing the metal concentration. The data (Fig. 4) showed that complete separation occurred up to the previous ratio of 1:1. Above such a ratio of increasing $\mathrm{V}(\mathrm{IV})$, curve $\mathrm{b}$ in Fig. 4 attains a degradation to a lower separation percentage. This reflects that an insufficient amount of HMBPT ligand was present for complete complexation, and hence indirect separation. $\mathrm{V}(\mathrm{V})$, on the other hand, was not floated at any molar ratio using the same recommended separation conditions (Fig. 4 , curve c).

\section{Influence of the HOL concentration}

The floatability of V(IV) at different concentrations of HOL in the absence (Fig. 5, curve a) and presence (curve b) of HMBPT was investigated. Curve a shows that the floatability of V(IV) slightly increased and reached $12.5 \%$ over a wide concentration range of HOL, and then again slightly decreased.

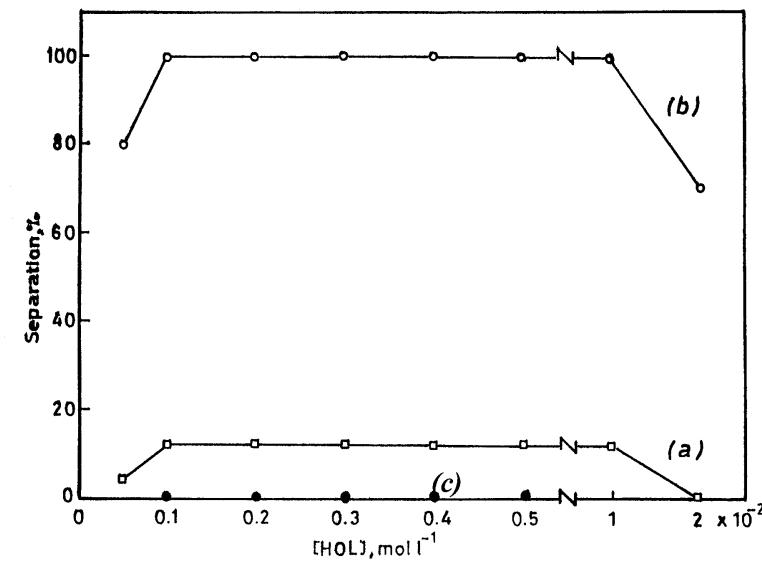

Fig. 5 Influence of the oleic acid concentration (HOL) on the separation efficiency of $\mathrm{V}(\mathrm{IV})$ and $\mathrm{V}(\mathrm{V})$ : curve a, $5 \times 10^{-5} \mathrm{~mol} \mathrm{~L}^{-1}$ $\mathrm{V}(\mathrm{IV})$ in the absence of HMBPT; curve b, $5 \times 10^{-5} \mathrm{~mol} \mathrm{~L}^{-1} \mathrm{~V}(\mathrm{IV})$ in the presence of $1 \times 10^{-4} \mathrm{~mol} \mathrm{~L}^{-1} \mathrm{HMBPT}$; curve c, $5 \times 10^{-5} \mathrm{~mol} \mathrm{~L}^{-1}$ $\mathrm{V}(\mathrm{V})$ in the absence or presence of $1 \times 10^{-4} \mathrm{~mol} \mathrm{~L}^{-1} \mathrm{HMBPT}$ at $\mathrm{pH}$ $\approx 1.5$.

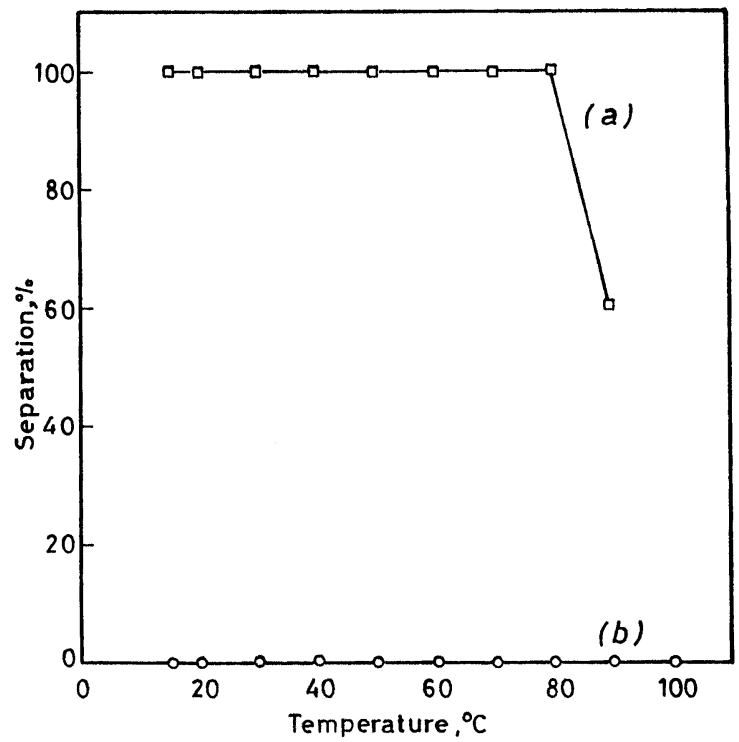

Fig. 6 Influence of the temperature on the separation efficiency of $2 \times 10^{-5} \mathrm{~mol} \mathrm{~L}^{-1}$ of $\mathrm{V}(\mathrm{IV})$ and $\mathrm{V}(\mathrm{V})$, each at $\mathrm{pH} \approx 1.5$ using $1 \times 10^{-4}$ mol L ${ }^{-1}$ HMBPT and $3 \times 10^{-3} \mathrm{~mol} \mathrm{~L}^{-1} \mathrm{HOL}$. V(IV) (curve a) and $\mathrm{V}(\mathrm{V})$ (curve b).

Curve $\mathrm{b}$ shows a similar trend, but with a maximum floatability $(100 \%)$. Again, the effect of HMBPT is evident from a comparison of curves a and $b$. Thus, $3 \times 10^{-3} \mathrm{~mol} \mathrm{~L}^{-1} \mathrm{HOL}$ was used throughout this work.

\section{Influence of temperature}

The flotation efficiency of $5 \times 10^{-5} \mathrm{~mol} \mathrm{~L}^{-1}$ of $\mathrm{V}(\mathrm{IV})$, under the previous optimized conditions of $\mathrm{pH}$, HMBPT and HOL concentration, was studied at different temperatures. This was done by adding the recommended quantities of HMBPT and HOL quickly to the analyte solutions. The mixtures were introduced into flotation cells jacketed with $1 \mathrm{~cm}$ of fiberglass insulation. The flotation procedure was then followed. The obtained results indicated that the floatability of V(IV) was not affected by increasing the temperature up to $80^{\circ} \mathrm{C}$, as shown in 


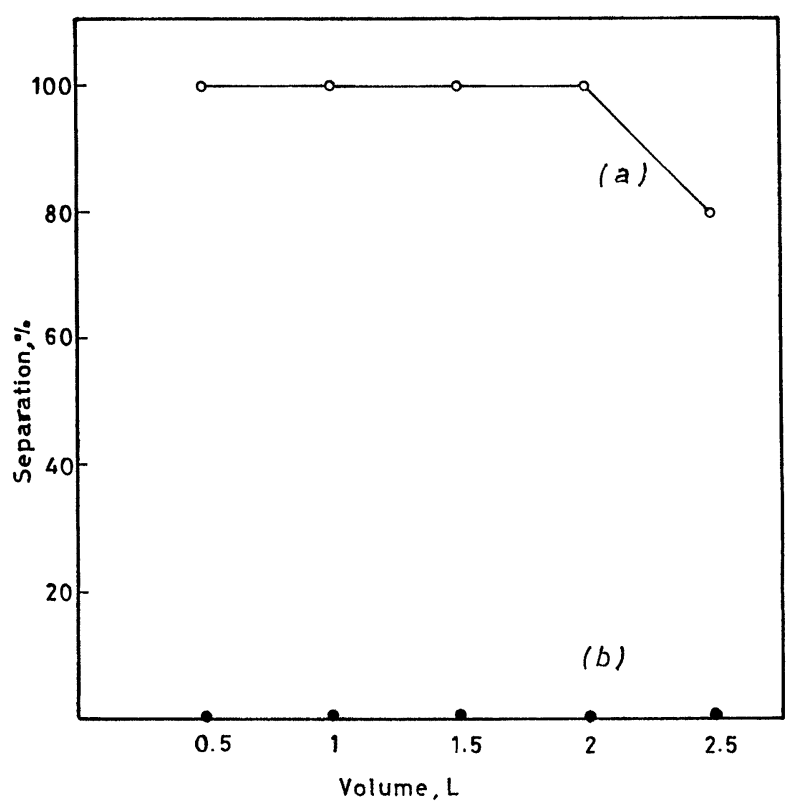

Fig. 7 Influence of dilution on the separation efficiency of $5 \times 10^{-5}$ mol L $\mathrm{L}^{-1} \mathrm{~V}(\mathrm{IV})$ and $\mathrm{V}(\mathrm{V})$, each under the recommended conditions. $\mathrm{V}(\mathrm{IV})$ (curve a) and $\mathrm{V}(\mathrm{V})$ (curve b).

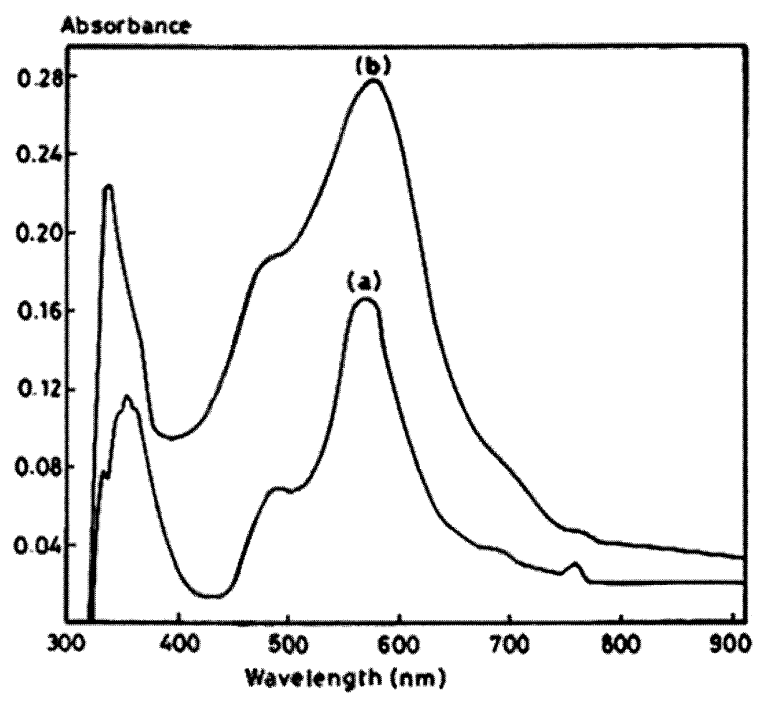

Fig. 8 Absorption spectra of V(IV)-HMBPT (curve a) and V(IV)HMBPT-HOL (curve b) solutions.

Fig. 6, curve a. Accordingly, the flotation procedure was carried out at room temperature i.e. $\sim 25^{\circ} \mathrm{C}$. Figure 6 , curve b, shows that $\mathrm{V}(\mathrm{V})$ was not floated at the studied temperatures under the recommended conditions.

\section{Induction time $(\tau)$}

The induction time $(\tau)$ is the time necessary to incorporate traces of the investigated microelement in the collector precipitate. The experiment showed that, under the prevailing conditions, HMBPT could quantitatively collect V(IV) during 1 $-3 \mathrm{~min}$. However, in practice an induction time of 5 min was sufficient to perform the investigation.

\section{Influence of volume}

Supposing that the detection limit of the separation procedure
Table 1 Influence of the ionic strength on the floatability of 1 $\times 10^{-5} \mathrm{~mol} \mathrm{~L}^{-1} \mathrm{~V}(\mathrm{IV})$ using $1 \times 10^{-4} \mathrm{~mol} \mathrm{~L}^{-1} \mathrm{HMBPT}$ and $3 \times$ $10^{-3} \mathrm{~mol} \mathrm{~L}^{-1} \mathrm{HOL}$ at $\mathrm{pH} \approx 1.5$ at room temperature $(n=5)$

\begin{tabular}{ccc}
\hline Ion & Concentration $/ \mathrm{mol} \mathrm{L}^{-1}$ & Separation rate $/ R$ \\
\hline $\mathrm{Na}(\mathrm{I})$ & 0.025 & 0.99 \\
& 0.050 & 0.99 \\
& 0.100 & 0.99 \\
$\mathrm{~K}(\mathrm{I})$ & 0.025 & 0.99 \\
& 0.050 & 0.99 \\
$\mathrm{Ca}(\mathrm{II})$ & 0.100 & 0.98 \\
& 0.025 & 0.99 \\
$\mathrm{Mg}(\mathrm{II})$ & 0.050 & 0.98 \\
& 0.100 & 0.98 \\
& 0.025 & 0.96 \\
& 0.050 & 0.98 \\
& 0.100 & 0.98 \\
\hline
\end{tabular}

is defined as the lowest quantity that can be quantitatively separated from a fixed volume, different experiments were carried out. Different concentrations of V(IV) were introduced into a fixed aqueous volume. Also, a fixed concentration of $\mathrm{V}(\mathrm{IV})\left(5 \times 10^{-5} \mathrm{~mol} \mathrm{~L}^{-1}\right)$ was separated from different aqueous volumes using a flotation cell (type 2 ) under the recommended conditions. The results (Fig. 7, curve a) show that $5 \times 10^{-5} \mathrm{~mol}$ $\mathrm{L}^{-1}$ of $\mathrm{V}(\mathrm{IV})$ can be quantitatively separated from different volumes up to $2 \mathrm{~L}$, above which $20 \%$ of the floated species decomposed in solution if the volume increased to $2.5 \mathrm{~L}$. Accordingly, the detection limit of such separation procedure was $1.27 \mathrm{ppm}$ of $\mathrm{V}(\mathrm{IV})$. Figure 7 , curve $\mathrm{b}$, shows that $\mathrm{V}(\mathrm{V})$ was not floated at any investigated volume of solution under the recommended conditions.

\section{Influence of the ionic strength}

Table 1 summarizes the effect of the ionic strength on the separation efficiency of $\mathrm{V}(\mathrm{IV})$ under the recommended conditions. The effect of $\mathrm{Na}, \mathrm{K}, \mathrm{Mg}$ and $\mathrm{Ca}$ as $\mathrm{Cl}^{-}, \mathrm{SO}_{4}^{-}, \mathrm{NO}_{2}{ }^{-}$ or $\mathrm{NO}_{3}{ }^{-}$forms was investigated; $\mathrm{Na}, \mathrm{K}, \mathrm{Ca}$ and $\mathrm{Mg}$ salts had no pronounced effect on the separation rate of the analyte (not more than 0.1 depression). These data introduce an excellent back ground for the separation of V(IV) from saline waters.

\section{Interferences}

The feasibility and amenability of analytical work depends not only on the degree of the interferences of the concomitants allied with the analyte species, but also on the degree of controlling such harmful effects. The effects of various ions that are naturally allied with $\mathrm{V}(\mathrm{IV})$ individually and in combination in their samples were studied during the flotation and determination of V(IV). The results, listed in Table 2, show that cations such as $\mathrm{Na}, \mathrm{K}, \mathrm{Ca}, \mathrm{Be}, \mathrm{Ti}, \mathrm{Zn}, \mathrm{Bi}, \mathrm{Sr}, \mathrm{Nb}, \mathrm{Co}, \mathrm{Ni}$, $\mathrm{Hg}, \mathrm{W}, \mathrm{Cr}, \mathrm{Mn}, \mathrm{Al}, \mathrm{Li}, \mathrm{Th}, \mathrm{Pb}, \mathrm{Cd}, \mathrm{Ba}, \mathrm{Zr}$ and $\mathrm{Hf}$ have no pronounced effect individually or in combination, even at higher concentrations. On the other hand, although cations such as $\mathrm{Fe}(\mathrm{III}), \mathrm{La}(\mathrm{III}), \mathrm{Sc}(\mathrm{III})$ and $\mathrm{Cu}(\mathrm{II})$ ions have some deleterious effect on the flotation separation and spectrophotometric determination of V(IV), these effects could be successfully eliminated (Table 3), using excess amounts of HMBPT ligand and/or $\mathrm{Na}_{2} \mathrm{~S}_{2} \mathrm{O}_{3}\left(0.1 \mathrm{~mol} \mathrm{~L}^{-1}\right)$ as a masking agent. $\mathrm{V}(\mathrm{IV})$, the chelating ligand changes its color drastically to 
Table 2 Influence of foreign ions, individually or in combination, on the separation and determination of $2 \times 10^{-5}$ mol L-1 $\mathrm{V}(\mathrm{IV})$ at $\mathrm{pH} \approx 1.5$ in the presence of $1 \times 10^{-4} \mathrm{~mol} \mathrm{~L}^{-1}$ HMBPT using $3 \times 10^{-3} \mathrm{~mol} \mathrm{~L}^{-1} \mathrm{HOL}$

\begin{tabular}{|c|c|c|}
\hline Interfering ions & Conc., ppm & Separation, $\%$ \\
\hline $\mathrm{Na}(\mathrm{I})$ & 1000 & 99.8 \\
\hline $\mathrm{K}(\mathrm{I})$ & 1000 & 99.9 \\
\hline $\mathrm{Ca}(\mathrm{II})$ & 1000 & 99.8 \\
\hline $\mathrm{Be}(\mathrm{II})$ & 1000 & 98.9 \\
\hline Ti(IV) & 500 & 97.9 \\
\hline $\mathrm{Zn}(\mathrm{II})$ & 500 & 99.8 \\
\hline Bi(III) & 500 & 97.7 \\
\hline $\operatorname{Sr}(\mathrm{II})$ & 500 & 98.9 \\
\hline $\mathrm{Nb}(\mathrm{V})$ & 500 & 99.5 \\
\hline $\mathrm{Co}(\mathrm{II})$ & 500 & 99.4 \\
\hline $\mathrm{Ni}(\mathrm{II})$ & 500 & 99.8 \\
\hline $\mathrm{Hg}(\mathrm{II})$ & 500 & 99.8 \\
\hline $\operatorname{Mn}(\mathrm{II})$ & 500 & 98.00 \\
\hline $\mathrm{Al}(\mathrm{III})$ & 1000 & 98.5 \\
\hline W(III) & 1000 & 98.5 \\
\hline $\mathrm{Cr}(\mathrm{III})$ & 1000 & 97.9 \\
\hline $\mathrm{Li}(\mathrm{I})$ & 1000 & 99.8 \\
\hline Th(IV) & 1000 & 99.0 \\
\hline $\mathrm{Pb}(\mathrm{II})$ & 1000 & 97.5 \\
\hline $\mathrm{Cd}(\mathrm{II})$ & 1000 & 97.9 \\
\hline $\mathrm{Ba}(\mathrm{II})$ & 1000 & 99.9 \\
\hline Zr(IV) & 500 & 100 \\
\hline Hf(IV) & 500 & 100 \\
\hline $\mathrm{Na}(\mathrm{I})+\mathrm{K}(\mathrm{I})$ & 500 & 100 \\
\hline $\mathrm{Ca}(\mathrm{II})+\mathrm{Li}(\mathrm{I})$ & 500 & 100 \\
\hline $\mathrm{Zn}(\mathrm{II})+\operatorname{Co}(\mathrm{II})$ & 500 & 99.00 \\
\hline $\mathrm{Cd}(\mathrm{II})+\mathrm{Al}(\mathrm{III})$ & 500 & 98.00 \\
\hline $\mathrm{W}(\mathrm{III})+\mathrm{Ti}(\mathrm{IV})$ & 500 & 98.5 \\
\hline $\operatorname{Co}(\mathrm{II})+\mathrm{Mn}(\mathrm{II})$ & 500 & 97.5 \\
\hline $\mathrm{Sr}(\mathrm{II})+\mathrm{Ni}(\mathrm{II})$ & 500 & 98.9 \\
\hline $\operatorname{Hg}(\mathrm{II})+\mathrm{Zn}(\mathrm{II})$ & 500 & 99.0 \\
\hline $\operatorname{Th}(\mathrm{IV})+\mathrm{Zr}(\mathrm{IV})$ & 500 & 99.0 \\
\hline $\mathrm{Zr}(\mathrm{IV})+\mathrm{Ni}(\mathrm{II})+\mathrm{Hg}(\mathrm{II})$ & 500 & 99.5 \\
\hline $\mathrm{Pb}(\mathrm{II})+\mathrm{Li}(\mathrm{I})+\mathrm{Al}(\mathrm{III})$ & 1000 & 98.5 \\
\hline $\mathrm{Cd}(\mathrm{II})+\mathrm{Ba}(\mathrm{II})+\mathrm{Zr}(\mathrm{IV})$ & 1000 & 98.4 \\
\hline $\mathrm{Sr}(\mathrm{II})+\mathrm{Co}(\mathrm{II})+\mathrm{Ni}(\mathrm{II})$ & 1000 & 99.0 \\
\hline $\mathrm{Ca}(\mathrm{II})+\mathrm{Co}(\mathrm{II})+\mathrm{Ni}(\mathrm{II})$ & 500 & 97.9 \\
\hline $\mathrm{Th}(\mathrm{IV})+\mathrm{Li}(\mathrm{I})+\mathrm{Cd}(\mathrm{II})$ & 500 & 97.8 \\
\hline $\mathrm{Na}(\mathrm{I})+\mathrm{K}(\mathrm{I})+\mathrm{Ni}(\mathrm{II})+\mathrm{Ca}(\mathrm{II})$ & 500 & 98.9 \\
\hline $\mathrm{Na}(\mathrm{I})+\mathrm{K}(\mathrm{I})+\mathrm{Co}(\mathrm{II})+\mathrm{Mn}(\mathrm{II})$ & 500 & 99.7 \\
\hline $\mathrm{Zn}(\mathrm{II})+\mathrm{Sr}(\mathrm{II})+\mathrm{Co}(\mathrm{II})+\mathrm{Zr}(\mathrm{IV})$ & 500 & 99.8 \\
\hline $\mathrm{Hg}(\mathrm{II})+\mathrm{Ni}(\mathrm{II})+\mathrm{Mn}(\mathrm{II})+\mathrm{Li}(\mathrm{I})$ & 500 & 99.5 \\
\hline
\end{tabular}

intense purple in accordance with the assumption that the V(IV) ions are bonded to the HMBPT by complex formation.

The absorption spectra of the V(IV)-HMBPT system in aqueous and scum layers are the same (Fig. 8, curves a and b). Different observations can be concluded from Fig. 8. $\lambda_{\max }(560$ $\mathrm{nm}$ ) of the V(IV)-HMBPT system (curve a) is identical with that of the V(IV)-HMBPT-HOL system (curve b) and the absorbance value of V(IV)-HMBPT-HOL is higher by several times than that of the V(IV)-HMBPT system. This proves that the species are highly concentrated in the presence of HOL. The complex formed in the scum layer exhibited two maxima at 350 and $560 \mathrm{~nm}$ (Fig. 8). Measurements at $350 \mathrm{~nm}$ were not satisfactory from an analytical point of view, in which Beer's law was not obeyed. Consequently, all following spectrophotometric measurements were recorded at $560 \mathrm{~nm}$.

Stoichiometry and stability. The stoichiometry of the complexes formed in aqueous and scum solutions was ascertained by applying the continuous-variation method. The

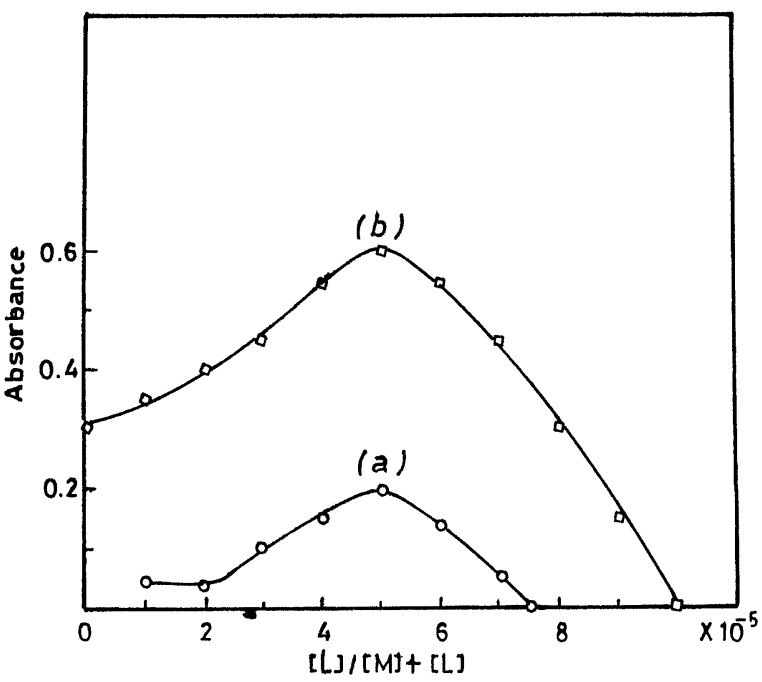

Fig. 9 Continuous-variation method for the V(IV)-HMBPT system at $560 \mathrm{~nm}$ (curve a) and the V(IV)-HMBPT-HOL system at $560 \mathrm{~nm}$ (curve b).

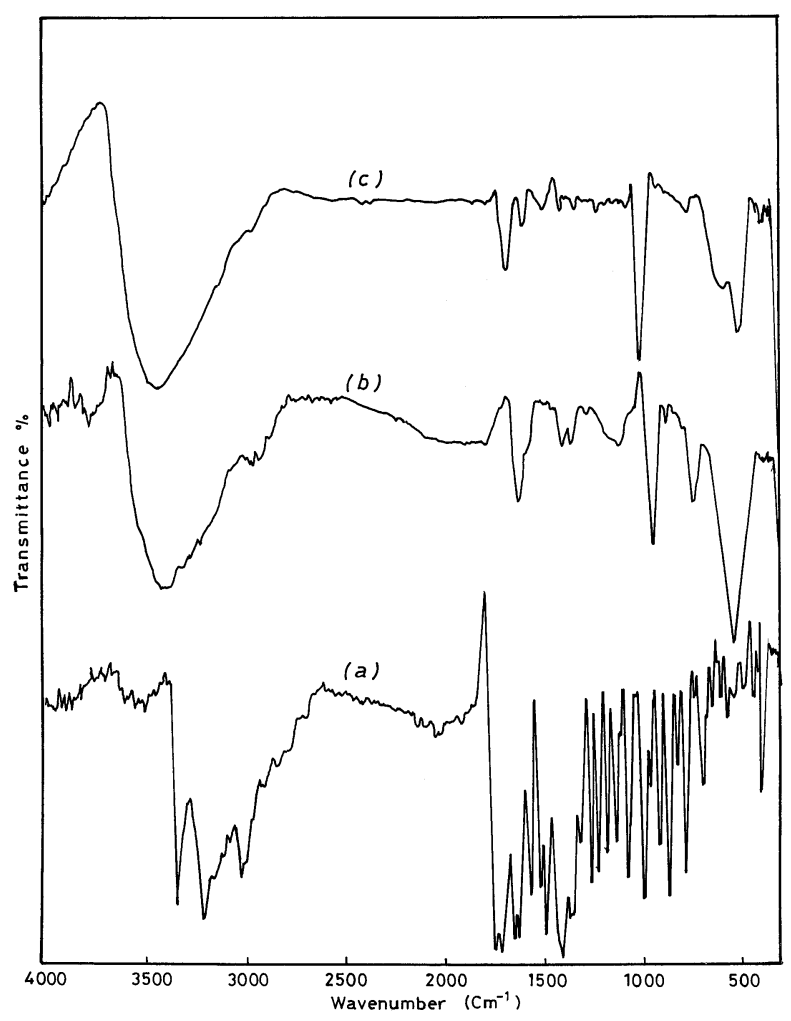

Fig. 10 Infrared spectra of (a) HMBPT alone, (b) V(IV)-HMBPT complex in the aqueous solution, (c) V(IV)-HMBPT complex in the scum layer.

results in Fig. 9 reveal the possible formation of the 1:1 V(IV)HMBPT species in the aqueous and scum systems. The apparent formation constants $\left(K_{\mathrm{f}}\right)$ of the complexes formed in the absence and presence of HOL were $8.7 \times 10^{5}$ and $4.5 \times 10^{7}$ $\mathrm{L} \mathrm{mol}^{-1}$, respectively. Thus, the stability of the species formed in the presence of HOL was higher than that obtained in its absence. Therefore, HOL stabilized the complex formed more than water.

Infrared spectra studies. The IR spectra (Fig. 10) of the 
Table 3 Influence of $\mathrm{Fe}(\mathrm{III}), \mathrm{Sc}(\mathrm{III}), \mathrm{La}$ (III) and $\mathrm{Cu}$ (II) ions individually or in combination on the separation and spectrophotometric determination of $2 \times 10^{-5} \mathrm{~mol} \mathrm{~L}^{-1} \mathrm{~V}(\mathrm{IV})$ in the presence of different concentrations of HMBPT using $3 \times$ $10^{-3} \mathrm{~mol} \mathrm{~L}-1 \mathrm{HOL}$ at $\mathrm{pH} \approx 1.5$ at room temp erature $(n=5)$

\begin{tabular}{lcccc}
\hline \multirow{2}{*}{ Interfering ion } & \multirow{2}{*}{$\begin{array}{c}\text { Concentration, } \\
\text { ppm, each }\end{array}$} & \multicolumn{3}{c}{ Separation, \% } \\
\cline { 3 - 5 } & & $\mathrm{A}$ & $\mathrm{B}$ & $\mathrm{C}$ \\
\hline $\mathrm{Fe}(\mathrm{III})$ & 500 & 75 & 89 & 100 \\
$\mathrm{La}(\mathrm{III})$ & 500 & 78 & 90 & 100 \\
$\mathrm{Sc}(\mathrm{III})$ & 500 & 70 & 87 & 100 \\
$\mathrm{Cu}(\mathrm{II})$ & 500 & 65 & 87 & 92 \\
$\mathrm{Cu}(\mathrm{II})+\mathrm{Fe}(\mathrm{III})$ & 500 & 63 & 85 & 89 \\
$\mathrm{Sc}(\mathrm{III})+\mathrm{Fe}(\mathrm{III})$ & 500 & 78 & 90 & 100 \\
$\mathrm{La}(\mathrm{III})+\mathrm{Fe}(\mathrm{III})$ & 500 & 79 & 90 & 100 \\
$\mathrm{Fe}(\mathrm{III})+\mathrm{Cu}(\mathrm{II})+\mathrm{La}(\mathrm{III})$ & 500 & 75 & 90 & 100 \\
$\mathrm{Fe}(\mathrm{III})+\mathrm{Sc}(\mathrm{III})+\mathrm{La}(\mathrm{III})$ & 500 & 71 & 86 & 100 \\
$\mathrm{Fe}(\mathrm{III})+\mathrm{Cu}(\mathrm{II})+\mathrm{La}(\mathrm{III})$ & 500 & 68 & 85 & 90 \\
\hline
\end{tabular}

A. In the presence of $1 \times 10^{-4} \mathrm{~mol} \mathrm{~L}^{-1} \mathrm{HMBPT}$.

B. In the presence of $2 \times 10^{-4} \mathrm{~mol} \mathrm{~L}^{-1} \mathrm{HMBPT}$.

C. In the presence of $4 \times 10^{-4} \mathrm{~mol} \mathrm{~L}^{-1} \mathrm{HMBPT}$.

Table 4 Analysis of $\mathrm{V}$ in certified reference materials after preconcentration using $4 \times 10^{-4} \mathrm{~mol} \mathrm{~L}^{-1} \mathrm{HMBPT}, 0.1 \mathrm{~mol} \mathrm{~L}^{-1}$ $\mathrm{Na}_{2} \mathrm{~S}_{2} \mathrm{O}_{3}$ and $3 \times 10^{-3} \mathrm{~mol} \mathrm{~L}^{-1} \mathrm{HOL}$ at $\mathrm{pH} \approx 1.5$ and at room temp erature $(n=5)$

\begin{tabular}{|c|c|c|c|c|c|c|}
\hline \multirow{2}{*}{ Sample } & \multicolumn{2}{|c|}{$\mathrm{V}, \mathrm{ppm}$} & \multirow{2}{*}{$\mathrm{AE}$} & \multirow{2}{*}{$\mathrm{RE}$} & \multirow{2}{*}{ SD } & \multirow{2}{*}{ RSD, \% } \\
\hline & Certified & Found & & & & \\
\hline Sample 1 & 0.30 & 0.293 & -0.007 & -2.3 & $2.1 \times 10^{-3}$ & 0.7 \\
\hline Sample 2 & 1.73 & 1.74 & 0.01 & 0.57 & 0.01 & 0.57 \\
\hline
\end{tabular}

$\mathrm{AE}$, absolute error.

RE, relative error.

Sample 1: Lead-zinc sulfide ore-OCrO (COD 161-96).

Sample 2: Stream sediment SARM 52.

HMBPT-V(IV) complexes in the aqueous layer and in the scum layer indicate that the protonated bidentate HMBPT ligand coordinates through the $\mathrm{S}=\mathrm{C}$ and $\mathrm{N}=\mathrm{C}$ groups. This is supported by the obvious lower shift from 787 to 746 or $740 \mathrm{~cm}^{-1}$, and from 1634 to 1624 or $1615 \mathrm{~cm}^{-1}$ for aqueous and floated complexes, respectively. The broad band observed in the IR spectra of the two complexes in the region $3200-3500 \mathrm{~cm}^{-1}$ excludes the assignment of $v(\mathrm{OH})$ vibration. The existence of the $\delta(\mathrm{OH})$ band, at the same position $\left(1347 \mathrm{~cm}^{-1}\right)$ as that in HMBPT indicates that the $\mathrm{OH}$ group does not take part in coordination. The new band observed at 954 and $917 \mathrm{~cm}^{-1}$ in the aqueous and floated complexes, respectively, is due to $v(\mathrm{VO})$ vibration. ${ }^{24}$ The existence of this band is similar to that reported for $\mathrm{VO}^{2+}$ complexes having a square pyramidal structure. 25

\section{Analytical figures of merits}

The applicability of HMBPT as a complexing agent for the flotation-spectrophotometric determination of $\mathrm{V}(\mathrm{IV})$ was studied at the concentrations up to $1 \times 10^{-4} \mathrm{~mol} \mathrm{~L}^{-1} \mathrm{~V}(\mathrm{IV})$ solution at $\mathrm{pH} 1.5$ using $1 \times 10^{-3} \mathrm{~mol} \mathrm{~L}^{-1} \mathrm{HMBPT}$ and $3 \mathrm{~mL}$ (3 $\left.\times 10^{-3} \mathrm{~mol} \mathrm{~L}^{-1}\right) \mathrm{HOL}$.

The effective molar absorption was calculated from data obtained by the measurements of the organic phase absorbance as the condition of flotation was completed. The obtained calibration graph was a straight line passing through the origin

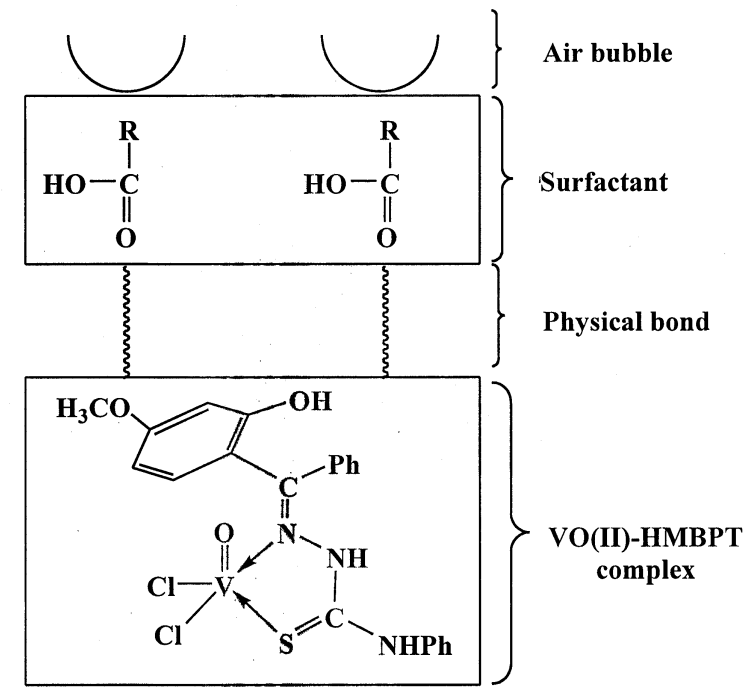

Scheme 3 Structure of the HMBPT-V(IV)-HOL system.

over the concentration range mentioned above. The effective molar absorption coefficients $(\varepsilon)$ at $\lambda_{\max } 560$ were $0.4 \times 10^{4}$ and $0.12 \times 10^{5} \mathrm{~L} \mathrm{~mol}^{-1} \mathrm{~cm}^{-1}$ in the aqueous layer and in the scum layer, respectively.

The complex obeyed Beer's law up to $1 \times 10^{-4} \mathrm{~mol} \mathrm{~L}^{-1}$ with an optimum range. The precision of the method was determined for ten different samples each containing $2 \times 10^{-5}$ mol L $\mathrm{L}^{-1}$ of $\mathrm{V}(\mathrm{IV})$ solution with a RSD of $3.2 \%$.

In order to validate the vanadium flotation procedure, the proposed method was applied to two certified reference materials viz.: lead-zinc sulfide ore-OCrO (COD 161-96) supplied by $\mathrm{MBH}$ Analytical Ltd. (Barnet, UK) and stream sediment SARM 52 prepared by MINTEX (Ranburg, Republic of South Africa).

The average contents of $\mathrm{V}$ found $(n=5)$ in the reference materials are given in Table 4 , with a precision as relative standard deviation of RSD $<1 \%$.

\section{Separation mechanism of $V(I V)$}

In the studies concerning the separation via flotation, the role of surfactant is very important. The nature of the interaction between an oleic acid surfactant and the formed V(IV)-HMBPT complex, must be studied to approach the actual mechanism of flotation. The proposed mechanism may proceed through physical adsorption, hydrogen-bond formation or an interaction between oleic acid and the complex formed in solution (some kind of bonds) forming a self-floatable (V(IV)-HMBPT-HOL) species. In these types of interactions, the hydrophobic part of the surfactant attaches to air bubbles and floats, separating the analyte-containing species.

In the present study, the flotation of V(IV)-HMBPT complex is proposed to proceed through physical adsorption. This behavior is supported by:

1. The V(IV) content in the aqueous complex: [found (Calcd.); 10.11 (9.87)] and in the floated complex: [found (Calcd.), 10.10 (9.87)] in the absence and presence of HOL is approximately similar, proving that the complex isolated from the scum layer is free from HOL and may have the formula [VO(HMBPT) $\mathrm{Cl}_{2}$ ].

2. The two complexes have the same color (purple), indicating that they may have the same geometry.

3. The melting points of the two complexes are high $\left(>300^{\circ} \mathrm{C}\right)$. 
Table 5 Determination of V(IV) and V(V) in each other's presence

\begin{tabular}{clccccccc}
\hline No. & Analyte & Added/ppm & Found/ppm & AE & RE & SD & RSD & Mean recovery, \% \\
\hline \multirow{2}{*}{1} & V(IV) & 0.51 & 0.53 & 0.02 & 3.92 & $8.16 \times 10^{-3}$ & 1.6 & $100 \pm 0.02$ \\
& V(V) & 0.51 & 0.51 & 0.0 & 0.0 & 0.01 & 1.96 & $100 \pm 0.01$ \\
2 & V(IV) & 2.55 & 2.54 & -0.01 & -0.39 & $7.07 \times 10^{-3}$ & 0.28 & $100 \pm 0.01$ \\
& V(V) & 2.55 & 2.56 & 0.01 & 0.39 & $7.07 \times 10^{-3}$ & 0.28 & $100 \pm 0.01$ \\
3 & V(IV) & 5.09 & 5.09 & 0.0 & 0.0 & 0.01 & 0.196 & $100 \pm 0.02$ \\
& V(V) & 5.09 & 5.07 & -0.02 & -0.39 & $7.07 \times 10^{-3}$ & 0.139 & $100 \pm 0.01$ \\
4 & V(IV) & 0.51 & 0.5 & -0.01 & -1.96 & 0.01 & 2.4 & $100 \pm 0.02$ \\
& V(V) & 5.09 & 5.09 & 0.0 & 0.0 & 0.01 & 0.196 & $100 \pm 0.01$ \\
5 & V(IV) & 2.55 & 2.53 & -0.02 & -0.78 & 0.01 & 0.39 & $100 \pm 0.01$ \\
& V(V) & 5.09 & 5.1 & 0.01 & 0.196 & -0.01 & 0.196 & $100 \pm 0.01$ \\
6 & V(IV) & 0.51 & 0.50 & -0.01 & -1.96 & $7.07 \times 10^{-3}$ & 1.39 & $100 \pm 0.02$ \\
& V(V) & 25.55 & 25.53 & -0.02 & -0.08 & 0.015 & 0.06 & $100 \pm 0.01$ \\
\hline
\end{tabular}

$\mathrm{AE}$, absolute error; RE, relative error; $\mathrm{SD}$, standard deviation; RSD, relative standard deviation. Conditions: HMBPT, $4 \times 10^{-4} \mathrm{~mol} \mathrm{~L}^{-1}$; HOL, $3 \times 10^{-3} \mathrm{~mol} \mathrm{~L}^{-1} ; \mathrm{pH} \approx 1.5$ at room temperature.

Table 6 Determination of $\mathrm{V}(1 \mathrm{~V})$ in synthetic mixtures of foreign ions

\begin{tabular}{|c|c|c|c|c|c|c|c|c|}
\hline \multirow{2}{*}{ No. } & \multirow{2}{*}{$\begin{array}{l}\text { Synthetic mixture, } \\
100 \text { ppm each }\end{array}$} & \multicolumn{2}{|c|}{$\mathrm{V}(\mathrm{IV}), \mathrm{ppm}$} & \multirow{2}{*}{$\mathrm{AE}$} & \multirow{2}{*}{$\mathrm{RE}$} & \multirow{2}{*}{ SD } & \multirow{2}{*}{ RSD } & \multirow{2}{*}{ Mean recovery, $\%$} \\
\hline & & Added & Found & & & & & \\
\hline 1 & $\mathrm{Co}(\mathrm{II})+\mathrm{Ni}(\mathrm{II})+\mathrm{Zn}(\mathrm{II})$ & 1.02 & 1.02 & 0 & 0 & $8.16 \times 10^{-3}$ & 0.8 & $100 \pm 0.02$ \\
\hline 2 & $\mathrm{~Pb}(\mathrm{II})+\mathrm{Ni}(\mathrm{II})+\mathrm{Cd}(\mathrm{II})$ & 1.02 & 1.03 & 0.01 & 0.98 & $8.16 \times 10^{-3}$ & 0.8 & $100 \pm 0.01$ \\
\hline 3 & $\mathrm{Al}(\mathrm{III})+\mathrm{Hg}(\mathrm{II})+\mathrm{Th}(\mathrm{IV})$ & 1.02 & 1.01 & -0.01 & -0.98 & $8.66 \times 10^{-3}$ & 0.85 & $100 \pm 0.01$ \\
\hline 4 & $\mathrm{Hf}(\mathrm{IV})+\mathrm{Mn}(\mathrm{II})+\mathrm{Zr}(\mathrm{IV})$ & 1.02 & 1.02 & 0 & 0 & $1 \times 10^{-2}$ & 0.98 & $100 \pm 0.02$ \\
\hline
\end{tabular}

Conditions: HMBPT, $4 \times 10^{-4} \mathrm{~mol} \mathrm{~L}^{-1}$; HOL, $3 \times 10^{-3} \mathrm{~mol} \mathrm{~L}^{-1} ; \mathrm{pH} \approx 1.5$ at room temperature $(n=5)$.

4. The molar conductivity for $10^{-3} \mathrm{M}$ solutions of the two complexes has 18 and $20 \mathrm{ohm}^{-1} \mathrm{~cm}^{2} \mathrm{~mol}^{-1}$ values for the aqueous and floated species. These values are in agreement with the non-conducting complexes. ${ }^{26}$

5. The electronic spectra of the solid complexes isolated in both aqueous and floated layers in DMF solution show typical spectra. Both have a band at $17920 \mathrm{~cm}^{-1}$, which is typical for the bands observed in a square-pyramidal geometry around the vanadyl ion. ${ }^{25}$

6. The two complexes have the same absorption spectra (Fig. 7) with $\lambda_{\max }$ at $560 \mathrm{~nm}\left(17920 \mathrm{~cm}^{-1}\right)$. This value is similar to that obtained by measuring the electronic spectra (17920 $\mathrm{cm}^{-1}$ ) of the solid complexes. This behavior indicates that the formed complexes in solid and in solution are similar. Also, the appearance of the band at $780 \mathrm{~nm}\left(12820 \mathrm{~cm}^{-1}\right)$ is characteristic for the existence of the complex in a squarepyramidal geometry.

7. The IR spectra of the HMBPT-V(IV) complexes in the aqueous layer and in the scum layer (Fig. 10) are nearly identical to each other. This is a finding that would exclude bonding between the V(IV)-HMBPT complex and HOL.

All of these data support that the complex between V(IV) and HMBPT is similar in nature in the aqueous layer and the scum layer. Accordingly, the separation mechanism is most probably due to physical adsorption through van der Waals force between the species containing V(IV)-HMBPT and the surfactant. A suitable structure is represented schematically in Scheme 3.

\section{Analytical applications}

Determination of $V(I V)$ and $V(V)$ in each other's presence. Many of the methods for measuring the total vanadium rely on either the oxidation or reduction of vanadium in the sample to a common oxidation state, which then forms a colored complex with various reagents. The reduction of vanadium present in a sample to the tetravalent state can reduce interferences from the lower valence states of elements, such as iron, chromium and manganese, which interfere ${ }^{27}$ with equivalent spectrophotometric methods for $\mathrm{V}(\mathrm{V})$. The reduction of $\mathrm{V}(\mathrm{V})$ to $\mathrm{V}(\mathrm{IV})$ can be achieved by various compounds such as ascorbic acid, ${ }^{28}$ hydroxylamine hydrochloride, ${ }^{29}$ and recently oxalic acid. ${ }^{30}$ In the present study, ascorbic acid was used to reduce all vanadium to the tetravalent state, which formed a colored (purple) complex with HMBPT that was easily separated by HOL surfactant and monitored spectrophotometrically or colorimetrically at $560 \mathrm{~nm}$.

In order to assess the selectivity of the proposed method for V(IV), it was applied to various synthetic samples containing different concentrations of V(IV) and V(V). In Table 5, it can be observed that the two species of $\mathrm{V}$ were completely separated and recovered quantitatively using the proposed method. The flotation methodology was thus shown to have an acceptable accuracy under different conditions, with recoveries of $\sim 100 \%$ for $\mathrm{V}(\mathrm{IV})$ and $\mathrm{V}(\mathrm{V})$.

In synthetic mixtures. The same procedure was also applied for the determination of V(IV) in synthetic mixtures of foreign ions (Table 6$)$ with a precision as RSD $<1 \%$ and a recovery $(R, \%)$ of $\sim 100 \%$.

Determination of $V(I V)$ in natural waters (recovery of $V(I V)$ ). The recovery results for V(IV), listed in Table 7, obtained from different water samples which were confirmed by the back titration method, indicate that the proposed method provides very good precision.

In simulated samples. The efficiency of the separation and determination of V(IV) from simulated CS C6 and CS C16 samples $^{31}$ is presented in Table 8 . 


\section{Conclusion}

Vanadium speciation is an attractive and difficult field of research in analytical chemistry, because $\mathrm{V}(\mathrm{IV})$ and $\mathrm{V}(\mathrm{V})$ have complex forms in aqueous solution which change in accordance with the solution $\mathrm{pH}$.

A new simple selective procedure for the separation and spectrophotometric determination of V(IV) using HMBPT as a complexing agent and HOL surfactant was developed in this work. Attractive features of this novel method include the rapid and quantitative separation of V(IV), a capability to remove interferences and the feasibility of determining V(IV) and V(V) in the presence of each other.

In the present study, V(IV) was enriched and successfully separated from media of diverse origin by ion flotation using HMBPT prior to its spectrophotometric determination. The recommended preconcentration procedure is fast (10 $\mathrm{min})$. The necessary equipment for flotation is simple and inexpensive. The use of a small amount of surfactant and tiny gas bubbles (vigorous shaking) necessary to perform a proper flotation cannot permit any serious contamination risks, which could be

Table 7 Recovery of $\mathrm{V}(\mathrm{IV})$ added to some natural-water samples after separation flotation using $4 \times 10^{-4} \mathrm{~mol} \mathrm{~L}^{-1}$ of HMBPT, $0.1 \mathrm{~mol} \mathrm{~L}^{-1} \mathrm{Na}_{2} \mathrm{~S}_{2} \mathrm{O}_{3}$ and $3 \times 10^{-3} \mathrm{~mol} \mathrm{~L}^{-1} \mathrm{HOL}$ at $\mathrm{pH}$ $\approx 1.5$ and at room temperature $(n=5)$

\begin{tabular}{clcc}
\hline No. & $\begin{array}{c}\text { Water sample } \\
\text { (Location) }\end{array}$ & $\begin{array}{c}\text { V(IV) added/ } \\
\times 10^{-4} \mathrm{~mol} \mathrm{~L}^{-1}\end{array}$ & Mean recovery, \% \\
\hline 1 & Bi-distilled water & 0.5 & $100 \pm 0.01$ \\
& & 1.0 & $100 \pm 0.01$ \\
2 & Domestic water & 0.5 & $100 \pm 0.01$ \\
& (Mansoura city) & 1.0 & $100 \pm 0.02$ \\
3 & Tank water & 0.5 & $100 \pm 0.01$ \\
& (Mansoura city) & 1.0 & $100 \pm 0.01$ \\
4 & Sea water & 0.5 & $100 \pm 0.02$ \\
& (Marsi-Matroah) & 1.0 & $100 \pm 0.02$ \\
5 & Sea water & 0.5 & $100 \pm 0.02$ \\
& (Ras-Elbar) & 1.0 & $100 \pm 0.03$ \\
6 & Sea water & 0.5 & $100 \pm 0.02$ \\
& (Gamasa) & 1.0 & $100 \pm 0.02$ \\
7 & Sea water & 0.5 & $100 \pm 0.02$ \\
& (Al-Areash) & 1.0 & $100 \pm 0.03$ \\
8 & Waste water & 0.5 & $110 \pm 0.08$ \\
& (Talkha power station) & 1.0 & $115 \pm 0.08$ \\
9 & Waste water & 0.5 & $115 \pm 0.07$ \\
& (Demiata power station) & 1.0 & $117 \pm 0.08$ \\
\hline
\end{tabular}

manifested by high blank volumes.

In the present investigation, the authors introduced HMBPT as a new reagent to the field of flotation-separation and spectrophotometric determination of V(IV) in media of diverse origin. The molar absorpitivity value of the complex V(IV)HMBPT $\left(0.12 \times 10^{5} \mathrm{~L} \mathrm{~mol}^{-1} \mathrm{~cm}^{-1}\right)$ reveals that the reagent HMBPT compares well, or is more sensitive, for V(IV) than reagents reported previously for the spectrophotometric determination of V(IV) such as, chrome azurole, ${ }^{32,33}$ Eriochrome Cyanine R, ${ }^{32,34,35}$ Catechol Violet, ${ }^{36}$ and trihdyroxy fluorine dyes. ${ }^{37,38}$

One of the most important advantages of the recommended method is the ability to analyze a larger volume of sample solution, and to obtain a great preconcentration factor, as well as excellent recoveries of the investigated trace element. The effective flotation using only HOL indicates that the addition of HMBPT makes the sublate sufficiently hydrophobic, and does not need more surfactants. A number of associated elements do not interfere with vanadium(IV) determination. The selectivity of the reagent is also improved by the judicial use of some masking agents, such as $\mathrm{Na}_{2} \mathrm{~S}_{2} \mathrm{O}_{3}$, to suppress the interference of some metal ions, like $\mathrm{Fe}(\mathrm{III}), \mathrm{La}(\mathrm{III}), \mathrm{Sc}(\mathrm{III})$ and $\mathrm{Cu}(\mathrm{II})$. This method has great potentiality for the successful determination of V(IV) in real ore as well as simulated, synthetic and environmental samples.

We hope in the future that the proposed procedure will be used not only in the separation of vanadium from ash oils of power stations, but also to separate $\mathrm{V}(\mathrm{IV})$ from $\mathrm{V}(\mathrm{V})$ and to apply this work for measuring the efficiency of the inhibitors by determining both $\mathrm{V}(\mathrm{IV})$ and $\mathrm{V}(\mathrm{V})$ in ash oils.

\section{References}

1. S. A. Abbasi, Anal. Lett., 1987, 1347.

2. R. Gracia-Sanchez, J. Betterman, and C. Ebdon, Michrochem. J., 2004, 76, 161.

3. S. Vermaire and R. de Haan, Ind. Eng. Chem. Res., 1988, $27,1241$.

4. G . A. Whittlow, S. E. Lee, R. R. Mullir, R. A. Wenglar and T. P. Sherlock, J. Eng. For Power, 1988, 105, 88.

5. G. G. Stevens and D. Tidy, J. Inst. Energy, 1981, 54, 30.

6. K. Hirayama, S. Kageyama, and N. Unchura, Analyst, 1992, 117, 13.

7. K. Hirayama and D. E. Leyden, Anal. Chim. Acta, 1980, $188,1$.

8. J. M. Bossque-Sendra, M. C. Valencia, and S. Boudrs, Fresenius J. Anal. Chem., 1998, 360, 31.

Table 8 Analysis of V(IV) in some simulated samples, after preconcentration using $4 \times 10^{-4} \mathrm{~mol} \mathrm{~L}^{-1} \mathrm{HMBPT}_{0} 0.1 \mathrm{~mol} \mathrm{~L}^{-1} \mathrm{Na}_{2} \mathrm{~S}_{2} \mathrm{O}_{3}$ and $3 \times 10^{-3} \mathrm{~mol} \mathrm{~L}^{-1} \mathrm{HOL}$ at $\mathrm{pH} \approx 1.5$

\begin{tabular}{|c|c|c|c|c|c|c|c|}
\hline \multirow{2}{*}{$\begin{array}{l}\text { Simulated sample } \\
\text { (composition, \%) }\end{array}$} & \multicolumn{2}{|c|}{$\mathrm{V}, \%$} & \multirow{2}{*}{$\mathrm{AE}$} & \multirow{2}{*}{$\mathrm{RE}$} & \multirow{2}{*}{ SD } & \multirow{2}{*}{ RSD } & \multirow{2}{*}{ Mean recovery, $\%$} \\
\hline & Certificate & Found & & & & & \\
\hline $\begin{array}{l}\text { CS C6 (Walframkarbid) } \\
\text { (C: 6.75, Al: 0.01, P: 0.001, S: 0.001, Ti: } \\
\text { 7.40, Fe: 0.10, Co: 6.80, Ni:--, Zn: 0.005, } \\
\text { Nb: 0.35, Hf: 0.005, Ta: 11.0, W: 67.5) }\end{array}$ & 0.01 & 0.01005 & $5 \times 10^{-5}$ & 0.5 & $1.4 \times 10^{-5}$ & 0.14 & $100 \pm 0.01$ \\
\hline $\begin{array}{l}\text { CS C16 (Tungesten Carbide) } \\
\text { (C: } 5.50, \text { Al: } 0.01, \text { P:0.002, S:0.002, } \\
\text { Ti:0.005, Fe:0.05, Co:10.00, Ni:0.001, } \\
\text { Zn:0.001, Nb:0.15, Hf:0.005, Ta:0.02, } \\
\text { W:84.0) }\end{array}$ & 0.005 & $5.006 \times 10^{-3}$ & $6 \times 10^{-6}$ & 0.12 & $6.5 \times 10^{-5}$ & 1.3 & $100 \pm 0.01$ \\
\hline
\end{tabular}


9. M. A. Akl, M. E. Khalifa, S. E. Ghazy, and M. M. Hassanein, Anal. Sci., 2002, 18, 1235.

10. M. E. Khalifa, M. A. Akl, and S. E. Ghazy, Chem. Pharm. Bull., 2002, 46, 664 .

11. M. A. Kabil, M. A. Akl, and M. E. Khalifa, Anal. Sci., 1999, 15, 433.

12. M. A. Akl, M. A. Kabil, A. M. Abdallaha, and D. S. Ismael, Sep. Sci. Technol., 2001, 36, 2747.

13. M. A. Kabil, M. A. Akl, A. M. Abdallah, and D. S. Ismael, Anal. Sci. 2000, 16, 713.

14. M. A. Akl, M. A. Kabil, A. M. Abdallaha, and D. S. Ismael, Bull. Chem. Soc., 2003, 76, 1543.

15. A. M. Abdallaha, M. A. Kabil, M. A. Akl, and D. S. Ismael, JICS, 2004, 1, 179.

16. S. E. Ghazy, M. A. Kabil, A. A. El-Asmy, and Y. E. Sherif, Afinidad, 1995, 456, 128.

17. M. A. Kabil, S. E. Ghazy, A. A. El-Asmy, and Y. E. Sherif, Anal. Sci., 1996, 12, 4319.

18. M. A. Kabil, S. E. Ghazy, A. A. El-Asmy, and Y. E. Sherif, Fresinius J. Anal. Chem., 1997, 397, 401.

19. R. Lobiniski and Z. Marczenko, Anal. Sci., 1988, 4, 629.

20. S. E. Ghazy and M. A. Kabil, Bull. Chem. Soc., 1994, 76, 2098.

21. Y. E. Sherif, M. Sc. Thesis, 1995, Mansoura University, Mansoura, Egypt.

22. A. I. Vogel "A Text Book of Quantitative Inorganic Analysis", 1994, Longman, London.

23. P. C. Cole, J. M. Eckert, and K. L. Willliams, Anal. Chim.
Acta, 1983, 158, 61.

24. R. C. Bell and A.W. Castleman, J. Inorg. Chem., 1999, 38, 5709.

25. H. S. Yadav, Polyhedron, 1993, 129, 313.

26. W. J. Georg, Coord. Chem. Rev., 1971, 7, 81.

27. I. N. Lezanovskaya and V. I. Petrashen, Zh. Anal. Khim., 1962, 22, 1008.

28. N. C. Radcliffe and J. R. Parker, Anal. Chim. Acta, 1970, 52,9 .

29. M. J. C. Taylor and J. V. van Staden, Analyst, 1994, 119, 1263.

30. V. I. E. Bruyere, L. A. Gracia Roderas, P. J. Morando, and M. A. Blesa, J. Chem. Soc. Dalton Trans., 2001, 3593.

31. Breitlander Spektraeproben Ne. Mettale, 1991.

32. M. Jarosz and Z. Marczenko, Analyst, 1984, 109, 35.

33. C. K. Verma, S. K. Kulshreths, and O. Prakash, Chem. Anal. [Warsaw], 1983, 28, 669.

34. J. Azanaroz, J. C. Vidal, M. A. Navas, and C. Diaz, Indian J. Chem., Sec. A, 1990, 29, 1240.

35. V. N. Tikhonov and T. M. Anisinova, Zh. Anal. Khim., 1984, 38, 778 .

36. V. N. Tikhonov, A. M. Mikhoulova, I. A. Myasnikova, and V. I. Vanyurkina, Zh. Anal. Khim., 1983, 38, 216.

37. J. R. Verna, O. Prakash, and S. P. Mushran, Anal. Chim. Acta, 1970, 52, 357.

38. E. Asnus and J. Jahny, Fresinius J. Anal. Chem., 1972, 259, 269. 